\title{
VdPLP, A Patatin-Like Phospholipase in Verticillium dahliae, Is Involved in Cell Wall Integrity and Required for Pathogenicity
}

\author{
Xiliang Qi ${ }^{1,2,+}$, Xiaokang $\mathrm{Li}^{1,3,+}$, Huiming Guo ${ }^{1}$, Ning Guo ${ }^{3}$ and Hongmei Cheng ${ }^{1, *}$ \\ 1 Biotechnology Research Institute, Chinese Academy of Agricultural Sciences, Beijing 100081, China; \\ qiliangxi@163.com (X.Q.); lixiaokang2016@163.com (X.L.); guohuiming@caas.cn (H.G.) \\ 2 Zhengzhou Fruit Research Institute, Chinese Academy of Agricultural Sciences, Zhengzhou 450009, China \\ 3 School of Life Sciences, Anhui Agricultural University, Hefei 230036, China; Guoning@ahau.edu.cn \\ * Correspondence: chenghongmei@caas.cn; Tel.: +86-10-8210-6125 \\ + These authors contributed equally to this work.
}

Received: 31 January 2018; Accepted: 7 March 2018; Published: 13 March 2018

\begin{abstract}
The soil-borne ascomycete fungus Verticillium dahliae causes vascular wilt disease and can seriously diminish the yield and quality of important crops. Functional analysis of growthand pathogenicity-related genes is essential for revealing the pathogenic molecular mechanism of $V$. dahliae. Phospholipase is an important virulence factor in fungi that hydrolyzes phospholipids into fatty acid and other lipophilic substances and is involved in hyphal development. Thus far, only a few $V$. dahliae phospholipases have been identified, and their involvement in $V$. dahliae development and pathogenicity remains unknown. In this study, the function of the patatin-like phospholipase gene in $V$. dahliae (VdPLP, VDAG_00942) is characterized by generating gene knockout and complementary mutants. Vegetative growth and conidiation of VdPLP deletion mutants $(\triangle V d P L P)$ were significantly reduced compared with wild type and complementary strains, but more microsclerotia formed. The $\triangle V d P L P$ mutants were very sensitive to the cell-wall-perturbing agents: calcofluor white (CFW) and Congo red (CR). The transcriptional level of genes related to the cell wall integrity (CWI) pathway and chitin synthesis were downregulated, suggesting that VdPLP has a pivotal role in the CWI pathway and chitin synthesis in $V$. dahliae. $\triangle V d P L P$ strains were distinctly impaired in in their virulence and ability to colonize Nicotiana benthamiana roots. Our results demonstrate that $V d P L P$ regulates hyphal growth and conidial production and is involved in stabilizing the cell wall, thus mediating the pathogenicity of $V$. dahliae.
\end{abstract}

Keywords: Verticillium dahliae; patatin-like phospholipases; cell wall integrity; pathogenicity

\section{Introduction}

Verticillium dahliae, a soil-borne, filamentous fungal plant pathogen with wide distribution around the world, can attack many important crops such as cotton, soybean, potato, sugar beet and sunflower, causing significant crop losses annually [1,2]. It is a significant threat to cash-crop production. It also produces microsclerotia, dormant structures that can survive for many years in the soil and be induced to germinate by plant root exudates [3,4]. Hyphae colonize the plant root surface, and then form a narrow penetration peg that can penetrate the epidermal cells [5]. Hyphae grow intracellularly and intercellularly through the root cortex, enter the xylem vessels and colonize the xylem of the hypocotyl and leaves. Ultimately, water flow in the plant tissue is disrupted, causing the wilt symptoms, stunting, chlorosis and necrosis $[4,6]$. The molecular mechanisms underlying $V$. dahliae pathogenesis are complex and still not clear [4-8], so functional analyses of growth- and pathogenicity-related genes are crucial in developing new strategies to control $V$. dahliae. 
Here, we focused on fungal phospholipases, which are involved in hyphal development, virulence and signaling. Phospholipases, key metabolic enzymes needed by all living organisms, hydrolyze phospholipids into fatty acids and lipophilic substances and are classified by the specific site of bond cleavage in the phospholipid substrates [9]. Phospholipase A enzymes hydrolyze the 1-acyl ester $\left(\mathrm{PLA}_{1}\right)$ or the 2-acyl ester (PLA ${ }_{2}$ ) of phospholipids, and PLA enzyme actions produce free fatty acids and 2-acyl lysophospholipid (PLA 1 ) or 1-acyl lysophospholipid (PLA 2 [10,11]. Phospholipase B (PLB) enzymes possess hydrolytic activities that release sn- 1 and sn-2 fatty acids from a phospholipid and PLBs catalyze the release of the remaining fatty acid linked to the lysophospholipid by lysophospholipase activity. Additionally, some PLBs can transfer a free fatty acid to a lysophospholipid and produce a phospholipid by transacylase activity $[10,12,13]$. Phospholipase C (PLC) catalyzes hydrolysis of phosphatidylinositol 4,5-bisphosphate (PIP2) to two intracellular messengers, inositol 1,4,5-triphosphate (IP3) and diacylglycerol (DAG) [10,14,15]. Phospholipase D (PLD) hydrolyzes phosphatidylcholine (PC) at second phosphodiester bond to yield phosphatidic acid (PA) and choline or ethanolamine. PLDs can also transfer the phosphatidyl moiety of the substrate of certain nucleophiles such as ethanol, which produce phosphatidylethanol (PEt) by the unique transphosphatidylation activity $[9,10,16]$. Lower phospholipase activities of pathogenic yeast fungi (Candida albicans, Candida parapsilosis, and Saccharomyces cerevisiae) reduce adherence to epithelial cells and are less lethal to mice $[9,17]$. During the development of $C$. albicans blastospores, phospholipase activities are concentrated at the growing tips [18]. PLC stimulates calcium release from intracellular stores and participates in hyphal extension at the growing tips in filamentous fungus Neurospora crassa [19]. In addition, phosphoinositide-specific PLC plays an important role in vegetative growth and cell wall regeneration in Coprinopsis cinerea [20].

Phospholipases are also related to signaling messengers to elicit stress tolerance and hosts immune responses in fungi $[9,13,21]$. The expression of phospholipases is regulated by persistent starvation [21,22]. PLA 2 takes part in various physiological processes, such as phospholipids hydrolysis, signal transduction, and remodeling of cell membrane. Some secreted and membrane-bound $\mathrm{PLA}_{2}$ require $\mathrm{Ca}^{2+}$ to perform biological activities [10]. PLC catalyzes PIP2 to DAG and IP3. As second messengers, DAG and IP3 play an important role in the signal transduction cascade, DAG can activate protein kinase C (PKC) and IP3 can activate calcium channels $[14,19]$. In the symbiotic fungus Tuber borchii, TbSP1 is a novel $\mathrm{Ca}^{2+}$-activated phospholipase $\mathrm{A}_{2}$, which may take part in membrane remodeling and signal transduction during early stages of plant invasion [21]. PLCs cleave the glycerophosphate bond, thus are defined as phosphodiesterases [10]. PLDs hydrolyze PC to yield PA, which regulates the activation of the cAMP-specific phosphodiesterases (PDEs). PDEs and adenylyl cyclases (ACs) regulate the intracellular cAMP levels. cAMP signaling plays critical role in regulating multiple cellular responses $[23,24]$. In addition, high-affinity phosphodiesterase PdeH modulates intracellular cAMP levels, thereby regulates cAMP signaling, cellular development and pathogenicity of plant pathogenic fungus Magnaporthe oryzae [25-27]. MoMck1, as one of the components of the mitogen-activated protein kinase (MAPK), interacts with PdeH that regulates MAPK signaling pathway to regulate cell wall integrity $[25,28]$.

The cell wall integrity (CWI) pathway can activate a compensatory salvage mechanism when the cell wall is under stress conditions [27,29]. MAPK pathways respond properly to extracellular stimuli or environmental conditions, and then regulate appropriate cellular responses [29-31]. In model yeast $S$. cerevisiae, cell wall stress is one of MAPK cascades that mediate the CWI pathway $[30,31]$. The MAP kinase I (Slt2/Mpk1) becomes activated under different cell wall stress conditions, such as hyposmolality, chitin-binding agents (Calcofluor White (CFW) and Congo Red (CR)) and oxidative stress. The major components of yeast cell wall are synthesized and modified under the stress [32-34]. The response mediated by Slt2/Mpk1 is defined as CWI pathway [31,33].

The patatin-like phospholipases (PLPs) was described as lipid acyl hydrolases. PLPs catalyze the cleavage of fatty acids from membrane lipids, thereby influence membranes remodeling $[35,36]$. PLPs have serine-aspartate dyads and $\alpha / \beta$ hydrolase fold, which is structurally similar to PLA 2 . 
Meanwhile, PLPs have been shown to exhibit a PLA 2 -like activity [36,37]. PLPs show difference in substrate specificity. PLPs have broader substrate preference, while cytosolic $\mathrm{PLA}_{2} \mathrm{~S}$ show increased substrate specificity for arachidonic acid-containing lipids [36-38]. PLPs also do not contain a lid-like structure and are limited to interfacial activation [38]. Phospholipases have been studied in some plant pathogenic fungi, such as Fusarium graminearum [14] and M. oryzae [25,26,28]. The phospholipase C (FgPLC1) is considered to be closely related to regulation of development, stress responses and pathogenicity of $F$. graminearum [14]. cAMP phosphodiesterase PdeH regulates the intracellular cAMP levels, CWI and pathogenicity of $M$. oryzae $[25,26,28]$, while the function of the patatin-like phospholipase (encoded by VdPLP, VDAG_00942) remains unclear in V. dahliae. The relations among $V d \mathrm{PLP}$, cell wall integrity and fungal virulence are unknown. In this study, to investigate the function of $V d P L P$, we generated a deletion mutant $(\triangle V d P L P)$ of $V$. dahliae and characterized its growth and development, the stress tolerance and integrity of the cell wall, root penetration ability, and virulence in Nicotiana benthamiana.

\section{Materials and Methods}

\subsection{Fungal Strains, Plant Material and Culture Conditions}

V. dahliae strain 991 (V991, wild type (WT)) was kindly provided by Prof. Guiliang Jian from the Institute of Plant Protection, Chinese Academy of Agricultural Sciences (IPP, CAAS). N. benthamiana seedlings were planted in a growth chamber with $16 \mathrm{~h}$ of light $/ 8 \mathrm{~h}$ of dark and $60-70 \%$ relative humidity at $23-25^{\circ} \mathrm{C}$.

\subsection{Plasmid Construction and Fungal Transformation}

$\triangle V d P L P$ mutants were obtained by a homologous recombination method. The VdPLP knockout plasmid pGKO-VdPLP (pGKO2 [EcoRI]::VdPLP-5'::neo::VdPLP-3'::pGKO2 [HindIII]) was constructed as in previous research $[8,39]$. The $2600 \mathrm{bp}$ geneticin resistant cassette (neo) from pCAM-neo plasmid was amplified using primer pair neo-F/neo-R (Table 1). The $1074 \mathrm{bp}$ upstream sequence of $V d P L P$ were amplified from the $V$. dahliae genome with primer pairs VdPLP-5F/VdPLP-5R, and a $1092 \mathrm{bp}$ downstream sequence with primer pairs VdPLP-3F/VdPLP-3R (Table 1). Vector pGKO2 [40] was linearized by double digestion with enzymes EcoRI and HindIII. Three PCR fragments were inserted into the corresponding position of linearized pGKO2 (Figure 1A) using In-Fusion enzyme (Clontech, Mountain View, CA, USA).

For generating $V d P L P$ complementary plasmid pCM-Hyg-VdPLP, the full-length complementary DNA (cDNA) fragment of $V d P L P$, the TrpC promoter and Nos terminator were amplified from plasmid pCH-GFP and primers C-VdPLP-F/C-VdPLP-R, C-TrpC-F/C-TrpC-R and C-Nos-F/C-Nos-R (Table 1). Plasmid pCM-Hyg carrying the hygromycin B resistance gene $(h p h)$ was linearized with restriction enzymes $\mathrm{Kp} n \mathrm{I}$ and $\mathrm{XbaI}$, and the fragments were inserted into plasmid pCM-Hyg digested with In Fusion enzyme.

Mutant strains were obtained through protoplast transformation [41]. Plasmids pGKO-VdPLP, pCM-Hyg-VdPLP and pCAM-GFP were used to transform protoplasts of the obtained mutants. $\triangle V d P L P$ mutant strains were generated by inserting plasmid $\mathrm{pGKO}-V d P L P$ into the wild type strain of $V$. dahliae $(\mathrm{Vd}-\mathrm{wt})$. Plasmid pCM-Hyg-VdPLP was introduced into $\triangle V d P L P$ strains to generate $V d P L P$ complementary mutants $(\triangle V d P L P-C)$. GFP-tagged strains were generated by inserting plasmid pCAM-GFP carrying the eGFP gene and $h p h$ gene into Vd-wt and the $\triangle V d P L P$ strains.

\subsection{Confirmation of VdPLP Disruption, Complementation of $\triangle V d P L P$ Strains and Screening for GFP-Tagged Strains}

$V d P L P$ knockout mutants were cultivated and selected on potato dextrose agar (PDA) plates supplied with geneticin $(50 \mu \mathrm{g} / \mathrm{mL}) . \triangle V d P L P-C$ and GFP-tagged strains were selected in the presence of hygromycin B. After single-spore isolation, all isolates were grown in complete medium $(\mathrm{CM}, 6 \mathrm{~g} / \mathrm{L}$ 
yeast extract, $6 \mathrm{~g} / \mathrm{L}$ casein acid hydrolysate, $10 \mathrm{~g} / \mathrm{L}$ sucrose) for DNA extraction. All isolates were further confirmed by genomic PCR with the specific primers. VdPLP was analyzed by genomic PCR with primer pair VdPLP-J-F/VdPLP-J-R (Table 1) for successful homologous recombination and with neo-J-F/neo-J-R for detecting the neo gene. $\triangle V d P L P-C$ mutants were selected by genomic PCR with primer pairs VdPLP-J-F/VdPLP-J-R and hyg-F/hyg-R (Table 1) for the hph gene. GFP-labeled strains were examined for the $h p h$ gene with primer pair hyg-F/hyg-R and for fluorescence with a confocal laser scanning microscope (LSCM; LSM 700, Zeiss, Jena, Germany) using $488 \mathrm{~nm}$ excitation wavelength and band-pass 500 to $550 \mathrm{~nm}$ emission filters.

Table 1. List of primers used in this study.

\begin{tabular}{|c|c|}
\hline Primer Name & Primer Sequence \\
\hline neo-F & GTTTGCGGGCTGTCTTGACG \\
\hline neo-R & TACCTGTGCATTCTGGGTAA \\
\hline VdPLP-5F & GTACCCAATTCGAATTCCCAGCGGTTCGGGTAGTAGTAGA \\
\hline VdPLP-5R & CAAGACAGCCCGCAAACGTATAACCCCGCGGAGCAGTAA \\
\hline VdPLP-3F & CCCAGAATGCACAGGTAGACGCGCCACGACCTCAA \\
\hline VdPLP-3R & ACGGTATCGATAAGCTTTGCGTGCGAACATACTCCTCAT \\
\hline C-TrpC-F & TTGAAGGAGCATTTTTGGGC \\
\hline C-TrpC-R & ATCGATGCTTGGGTAGAATAGGT \\
\hline C-VdPLP-F & ATGCCTGTCAACGATATCCGTCT \\
\hline C-VdPLP-R & CTATTCCTCGATCAGAGAGTAG \\
\hline C-Nos-F & AGATGCCGACCGGGATCCACTT \\
\hline C-Nos-R & TTATCTTTGCGAACCCAGGG \\
\hline VdPLP-J-F & CTCGAGCGGGCCATCAAACA \\
\hline VdPLP-J-R & GAGTAAGCCACCCATCTGTCCGTT \\
\hline neo-J-F & GCGGTTCAGAAGCACCTCGA \\
\hline neo-J-R & TATCTTTGCGAACCCAGG \\
\hline VdMK1-F & CGCGCCCGAGATTATGCTGAG \\
\hline VdMK1-R & CGTTGGGAGTACCGAGGATGTGAA \\
\hline VdChi1-F & GCCGCCGCCTGGTCATC \\
\hline VdChi1-R & CGGGGTAGAGGTCGGCATCA \\
\hline VdChi3-F & GGTCGGCCCTTGGAGCAGTA \\
\hline VdChi3-R & CCCTTGGCAGCCTTGATGTAGC \\
\hline VdChi4-F & TACGGCAAGGTTTACTCGGGTCTC \\
\hline VdChi4-R & CGGTTGCCAGGCTTCGTCTTAC \\
\hline VdChi7-F & CATCCTCGGCGTCACAAAGTTCTA \\
\hline VdChi7-R & GCTGCCGCTGCTGGAGGTA \\
\hline VdBt-F & TTCCCCCGTCTCCACTTCTTCATG \\
\hline VdBt-R & GACGAGATCGTTCATGTTGAACTC \\
\hline $\mathrm{Nb}$-actin-F & GGACCTTTATGGAAACATTGTGCTCAGT \\
\hline $\mathrm{Nb}$-actin-R & CCAAGATAGAACCTCCAATCCAGACAC \\
\hline Vd-F & CCGCCGGTCCATCAGTCTCTCTGTTTATAC \\
\hline Vd-R & CGCCTGCGGGACTCCGATGCGAGCTGTAAC \\
\hline
\end{tabular}

\subsection{Growth, Conidia Production and Microsclerotia Formation Assays}

Vd-wt, $\triangle V d P L P$ and $\triangle V d P L P-C$ strains were cultured in $\mathrm{CM}$, conidia of each strain were harvested and filtered through a sterile $40 \mu \mathrm{m}$ cell strainer (Falcon, New York, NY, USA). Two microliters of $5 \times 10^{6} / \mathrm{mL}$ conidial suspension of all strains were added to the center of plates of minimal medium (MM, $1.45 \mathrm{~g} / \mathrm{L}$ $\mathrm{KH}_{2} \mathrm{PO}_{4} ; 2.05 \mathrm{~g} / \mathrm{L} \mathrm{K}_{2} \mathrm{HPO}_{4} ; 0.5 \mathrm{~g} / \mathrm{L} \mathrm{NH}_{4} \mathrm{NO}_{3} ; 0.01 \mathrm{~g} / \mathrm{L} \mathrm{CaCl}_{2} ; 0.6 \mathrm{~g} / \mathrm{L} \mathrm{MgSO}_{4} \cdot 7 \mathrm{H}_{2} \mathrm{O} ; 0.3 \mathrm{~g} / \mathrm{L} \mathrm{NaCl}$; $0.5 \mathrm{mg} / \mathrm{L} \mathrm{ZnSO} 4 \cdot 7 \mathrm{H}_{2} \mathrm{O} ; 0.5 \mathrm{mg} / \mathrm{L} \mathrm{CuSO}_{4} \cdot 5 \mathrm{H}_{2} \mathrm{O} ; 0.5 \mathrm{mg} / \mathrm{L} \mathrm{H}_{3} \mathrm{BO}_{3} ; 0.25 \mathrm{~g} / \mathrm{L}\left(\mathrm{NH}_{4}\right)_{2} \mathrm{SO}_{4} ; 0.5 \mathrm{mg} / \mathrm{L}$ $\mathrm{MnSO}_{4} \cdot \mathrm{H}_{2} \mathrm{O} ; 0.5 \mathrm{mg} / \mathrm{L} \mathrm{Na}_{2} \mathrm{MoO}_{4} \cdot 2 \mathrm{H}_{2} \mathrm{O} ; 20 \mathrm{~g} / \mathrm{L}$ agar) [6] amended with different carbon sources $(10 \mathrm{~g} / \mathrm{L}$ xylose; galactose; pectin; or starch; or $30 \mathrm{~g} / \mathrm{L}$ sucrose). Colony diameter and morphology were recorded as described previously [9]. Vd-wt, $\triangle V d P L P$ and $\triangle V d P L P-C$ strains were cultured on Czapek-Dox agar $\left(3.0 \mathrm{~g} / \mathrm{L} \mathrm{NaNO}_{3} ; 0.5 \mathrm{~g} / \mathrm{L} \mathrm{MgSO}_{4} \cdot 7 \mathrm{H}_{2} \mathrm{O} ; 0.5 \mathrm{~g} / \mathrm{L} \mathrm{KCl} ; 0.01 \mathrm{~g} / \mathrm{L} \mathrm{FeSO}_{4} \cdot 7 \mathrm{H}_{2} \mathrm{O} ; 1.0 \mathrm{~g} / \mathrm{L} \mathrm{K}_{2} \mathrm{HPO}_{4} ; 15 \mathrm{~g} / \mathrm{L}\right.$ agar) plates to assay conidia production as described previously [39]. For microsclerotia formation tests, $10^{6} / \mathrm{mL}$ 
spores of $\mathrm{Vd}-\mathrm{wt}, \triangle V d P L P$ and $\triangle V d P L P-\mathrm{C}$ strains were evenly spread on basal agar modified medium (BMM, $0.2 \mathrm{~g} / \mathrm{L} \mathrm{NaNO}_{3} ; 0.52 \mathrm{~g} / \mathrm{L} \mathrm{KCl} ; 0.52 \mathrm{~g} / \mathrm{L} \mathrm{MgSO}_{4} \cdot 7 \mathrm{H}_{2} \mathrm{O} ; 1.52 \mathrm{~g} / \mathrm{L} \mathrm{KH}_{2} \mathrm{PO}_{4} ; 3 \mu \mathrm{mol} / \mathrm{L}$ thiamine; $0.1 \mu \mathrm{mol} / \mathrm{L}$ biotin; $5 \mathrm{~g} / \mathrm{L}$ glucose; $15 \mathrm{~g} / \mathrm{L}$ agar) plates, then incubated at $25{ }^{\circ} \mathrm{C}$ for 21 days. At seven-day intervals, microsclerotia on plates were counted [42]. Each strain was tested on 10 plates, and the assay was done three times.

\subsection{Phenotype Assays Using Cell Wall-Disrupting Agents Calcoflour White and Congo Red}

Susceptibility to cell wall-perturbing agents CFW and CR is generally tested to detect cell wall mutants of mycelial fungi $[28,43]$. A conidial suspension of each strain $\left(10 \mu \mathrm{L}\right.$ of $\left.5 \times 10^{6} / \mathrm{mL}\right)$ was placed on the center of separate PDA agar plates containing $50 \mathrm{mg} / \mathrm{mL}$ CFW or $100 \mathrm{mg} / \mathrm{mL} \mathrm{CR}$, or without CR or CFW. Colony phenotypes were observed seven days after inoculation. The experiment was performed three times independently, using 10 plates per strain per treatment.

\subsection{Quantitative Real-Time PCR Reaction}

Cell wall reinforcement and repair in response to cell wall stress is activated by the CWI pathway, a basal cascade pathway triggered by transmembrane sensors in response to cell wall stress [44-46]. To examine the potential role of VdPLP in the CWI pathway and chitin synthesis, we analyzed the transcription levels of genes encoding mitogen-activated protein kinase kinase (VdMKK1, VDAG_09823) and mitogen-activated protein kinase (VdMK1, VDAG_09461) for the CWI pathway and chitin synthesis genes VdChi1 (VDAG_10179), VdChi3 (VDAG_08591), VdChi4 (VDAG_00419), VdChi7 (VDAG_01790) in the Vd-wt, $\triangle V d P L P$ and $\triangle V d P L P-C$ strains, which were grown in liquid CM for 5 days. Total RNA was extracted from each strain using the RNA miniprep kit (Axygen, Union City, CA, USA) according to the user's guide. cDNAs were synthesized with the TOYOBO RT Kit (TOYOBO, Osaka, Japan). The quantitative real-time PCR (qRT-PCR) reactions were performed with the SYBR Fast qPCR kit (KAPA Biosystems, Boston, MA, USA). Specific primers for different genes were designed (Table 1). The constitutively expressed $\beta$-tubulin gene (DQ266153) was used for normalization and amplified with primers VdBt-F/VdBt-R (Table 1). The qRT-PCR reactions were performed in an ABI7500 Fast PCR thermocycler (Applied Biosystems, Foster City, CA, USA). The experiment was repeated two times.

\subsection{Penetration Ability Assay}

Penetration was assayed as described previously [47,48]. About $20 \mu \mathrm{L}$ of $2 \times 10^{6} / \mathrm{mL}$ conidial suspension of each strain were placed on cellophane laid on PDA plates, then incubated at $25{ }^{\circ} \mathrm{C}$. After 3 days, the cellophane was removed from the plates, which were then incubated for 7 more days at $25^{\circ} \mathrm{C}$, and hyphae were observed. This assay was done three times, with five plates per strain each time.

For microscopically observing initial infection, roots of $N$. benthamiana seedlings with 6-7 true leaves were inoculated with GFP-labeled $V d$-GFP or $\triangle V d P L P$-GFP strains [8]. After 3 days, the roots were vertically cut and observed on temporary slides with LSCM.

\subsection{Pathogenicity Assays, Microscopic Observation of Initial Infection and Fungal Biomass Quantification}

For pathogenicity assay experiments, roots of $10 \mathrm{~N}$. benthamiana plants were inoculated with conidia of strain Vd-wt, $\triangle V d P L P$ or $\triangle V d P L P-C$ as previously described [39]. The disease symptoms were recorded at 8,10 , and 12 days post inoculation (dpi), and the mean of the disease grade was calculated as an indicator of the severity of the disease. Wilt symptoms were classified into five grades: 0 , no disease symptoms; 1 , wilting of fewer than two leaves; 2 , wilting of three to five leaves; 3 , wilting of more than five leaves; and 4 , death or near death of plants $[39,49]$.

Colonization ability of strains was assessed by quantifying the fungal biomass in N. benthamiana using qRT-PCR. DNA was extracted from infected plant stems using the DNAsecure Plant Kit (TIANGEN, Beijing, China). The actin gene of N. benthamiana was selected as an internal standard [8] 
and amplified with primer pair $\mathrm{Nb}$-actin-F/Nb-actin- $\mathrm{R}$ (Table 1). ITS1 and ITS2 regions of the ribosomal RNA genes (Z29511) of $V$. dahliae were amplified with primer pair Vd-F/Vd-R (Table 1), which was used to quantify the fungal DNA in the mixed DNA samples. All qRT-PCR reactions were done as previously reported [39].

\subsection{Statistical Analysis}

Significant difference of data among the groups was analyzed using Duncan's multiple range test ( $p$-value $<0.05$ ) and SPSS Statistics 17.0 software (SPSS, Chicago, IL, USA).

\section{Results}

\subsection{Deletion and Complementation of VdPLP in V. dahliae}

The VdPLP gene was replaced by the neo cassette in the Vd-wt strain. With the targeted gene replacement, geneticin resistance was generated. Transformations were confirmed by genomic PCR; homologous transformation events had occurred in 3 of 30 independent transformants of the Vd-wt strain. $V d P L P$ deletion mutants $(\triangle V d P L P-1$ and $\triangle V d P L P-4)$ were randomly selected for further functional analysis (Figure 1B,C). For complementation, the In-fusion-resulting plasmid was introduced into $\triangle V d P L P-1$ and $\triangle V d P L P-4$ strains by protoplast transformation (Figure 1D), resulting in complementary strains $\triangle V d P L P-1-C$ and $\triangle V d P L P-4-C$.

A
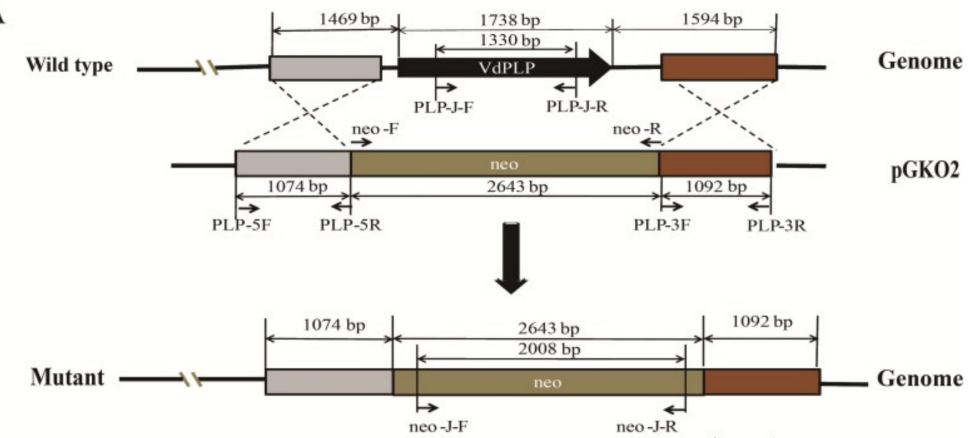

B
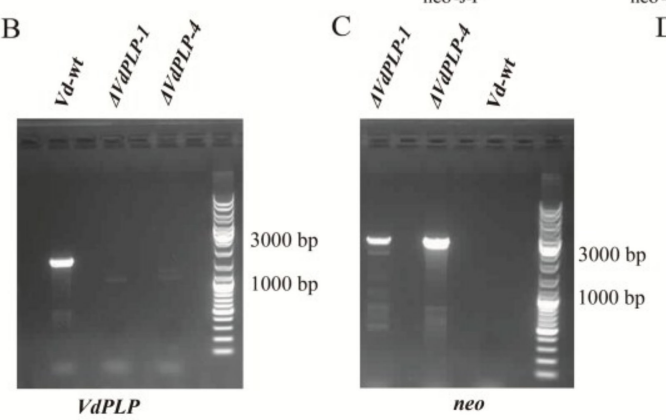

$\mathrm{D}$

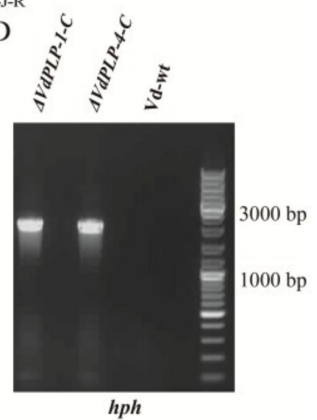

Figure 1. $V d P L P$ gene disruption in $V$. dahliae and complementation of the $\triangle V d P L P$ strains $(\triangle V d P L P-1$ and $\triangle V d P L P-4)$. (A) Disruption scheme used for $V d P L P$ in the wild type (wt) strain (Vd-wt); gene disruption was confirmed by PCR. Genomic DNA (gDNA) from the Vd-wt, $\triangle V d P L P$ and $\triangle V d P L P-C$ strains were used as templates for amplification with primer pairs VdPLP-J-F/VdPLP-J-R, neo-J-F/neo-J-R and hyg-F/hyg-R; (B) A 1.3-kb fragment of $V d P L P$ was amplified from Vd-wt with primer pair VdPLP-J-F/VdPLP-J-R; (C) A $2.6 \mathrm{~kb}$ fragment of neo was amplified with primer pair neo-J-F/neo-J-R from the $\triangle V d P L P$ mutant strains; (D) Gene complementation of the $\triangle V d P L P$ strains $(\triangle V d P L P-1-C$ and $\triangle V d P L P-4-C)$ was confirmed by amplification of a $1.6 \mathrm{~kb}$ fragment of hygromycin $\mathrm{B}$ resistance gene $(h p h)$ in PCR with primer pair hyg-F/hyg-R. 


\subsection{Radial Growth of Mycelia was Significantly Reduced in $\triangle$ VdPLP Mutants}

The effects of VdPLP disruption on hyphal growth were defined by growing Vd-wt and the mutants on MM agar with different carbon source (sucrose, pectin, starch, galactose or xylose) and comparing the phenotypes of each strain. Vegetative growth of $\triangle V d P L P$ mutants was severely retarded compared with that of Vd-wt, $\triangle V d P L P-1-C$ and $\triangle V d P L P-4-C$ strains, and colony diameter of the $\triangle V d P L P$ mutants was significantly smaller than that of Vd-wt, $\triangle V d P L P-1-C$ and $\triangle V d P L P-4-C$ strains (Figure 2B). These results suggested that the $V d P L P$ contributes to the hyphal growth of $V$. dahliae on different carbon sources.

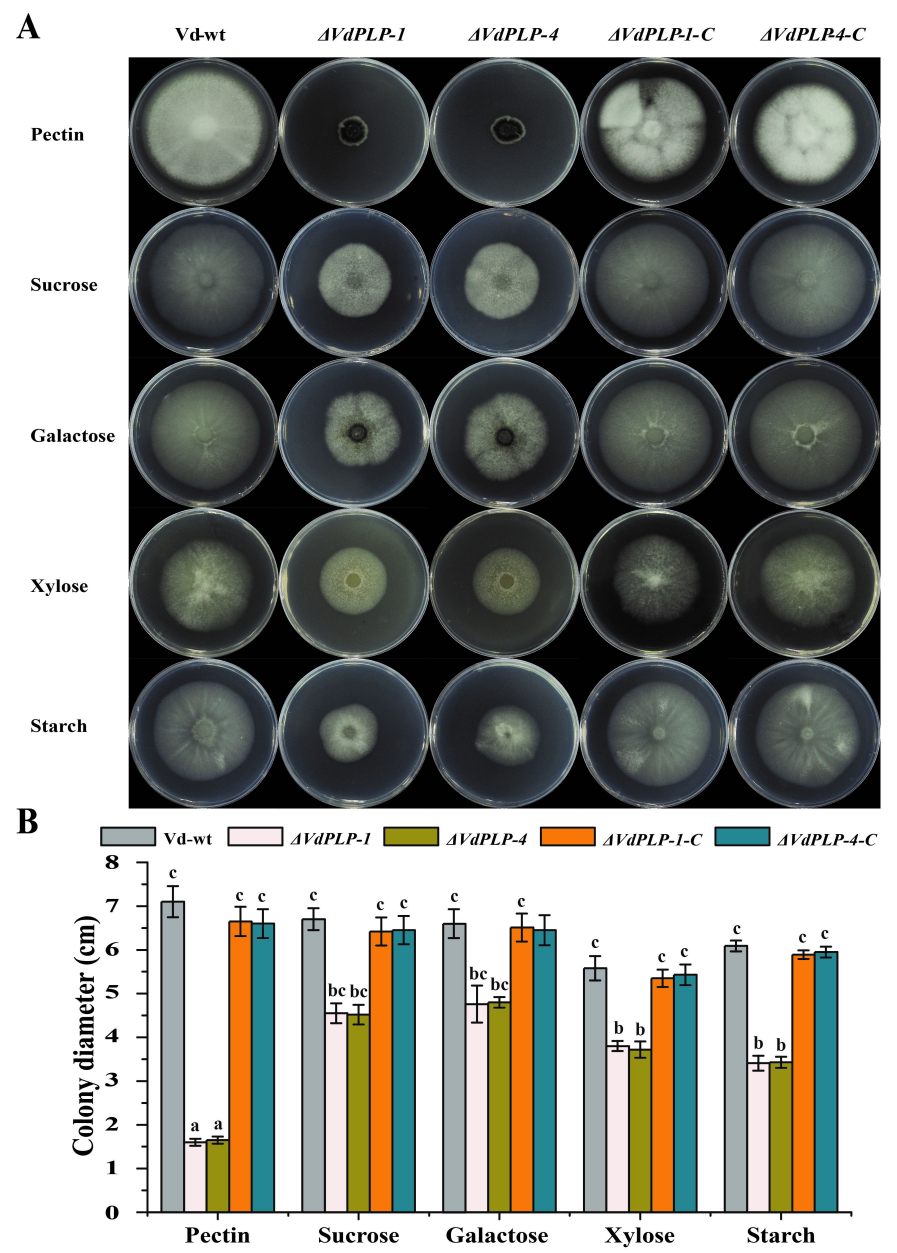

Figure 2. Mycelial growth of Vd-wt, $\triangle V d P L P(\triangle V d P L P-1$ and $\triangle V d P L P-4)$ strains and complementary $\triangle V d P L P$ strains ( $\triangle V d P L P-1-C$ and $\triangle V d P L P-4-C)$ strains after 15 days on minimal medium (MM) agar with different carbon sources: (A) colony morphology; and (B) colony diameters. Values represent the mean \pm standard deviation (SD) from three independent replicates, Different letters $(\mathrm{a}-\mathrm{c})$ above the bars represent the significant differences among the groups $(p$-value $<0.05)$ and the data were analyzed using Duncan's multiple range test.

\subsection{Conidiation by $\triangle V d P L P$ Mutants Decreased Substantially and Microsclerotia Formation Increased}

To check whether the deletion of VdPLP affects conidiation and microsclerotia formation, each strain was cultured on Czapek-Dox and BMM plates to enumerate conidia and microsclerotia after 15 days. Mutants $\triangle V d P L P-1$ and $\triangle V d P L P-4$ produced significantly fewer conidia on Czapek-Dox than did the $\mathrm{Vd}$-wt and complementation strains (Figure $3 \mathrm{~A}$ ). In addition, the $\triangle V d P L P$ mutant strains accumulated more melanin on BMM, while Vd-wt, $\triangle V d P L P-1-C$ and $\triangle V d P L P-4-C$ strains were light-colored and produced no melanin on BMM (Figure 3B). On BMM, the $\triangle V d P L P$ strains 
formed microsclerotia earlier and in greater numbers than did the $\mathrm{Vd}-\mathrm{wt}$ and the complementation strains (Figure 3C,D). The results indicated that deletion of the VdPLP gene accelerated melanin and microsclerotia production in $V$. dahliae.

A

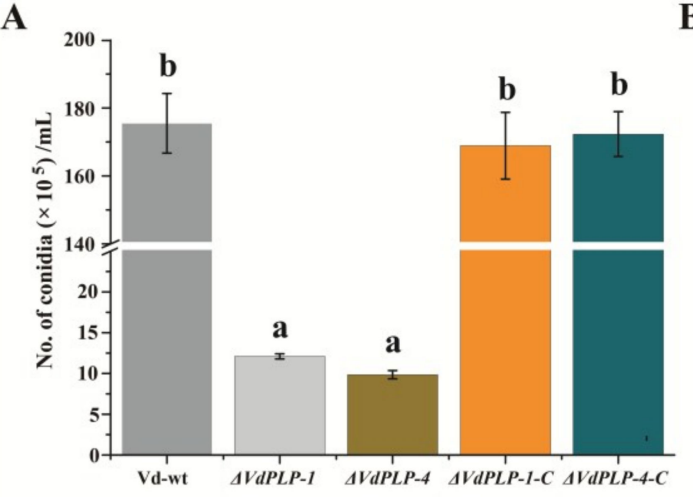

C

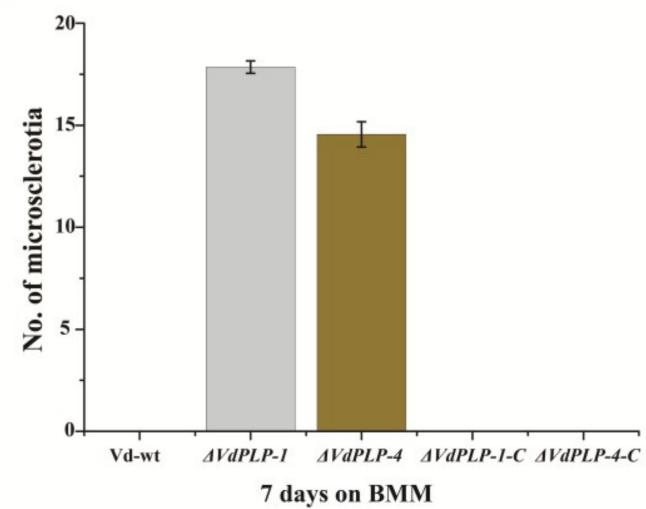

B

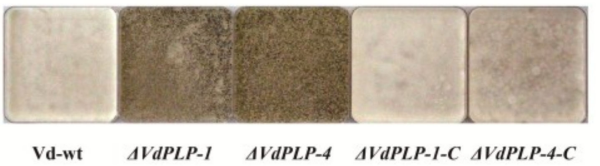

D

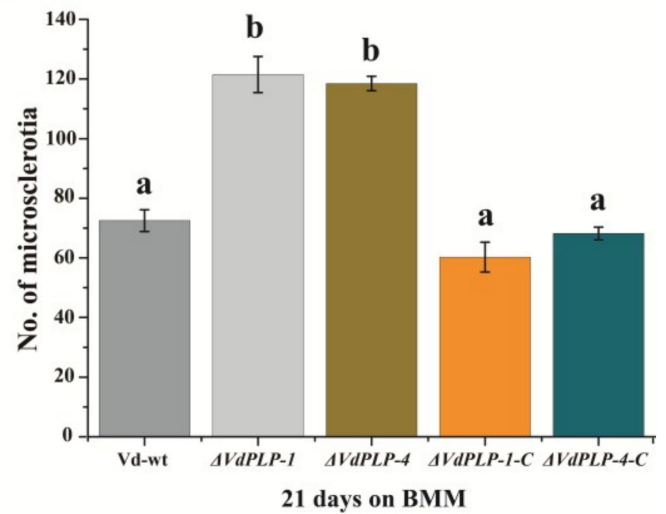

Figure 3. Deletion of $V d P L P$ reduces conidial production and increases microsclerotial formation. (A) Number of conidia produced by Vd-wt, $\triangle V d P L P$ strains ( $\triangle V d P L P-1$ and $\triangle V d P L P-4)$, and complementary $\triangle V d P L P$ strains $(\triangle V d P L P-1-C$ and $\triangle V d P L P-4-C)$ after 15 days on Czapek-Dox agar. (B) Colony color of Vd-wt, $\triangle V d P L P$ strains ( $\triangle V d P L P-1$ and $\triangle V d P L P-4)$, and complementary $\triangle V d P L P$ mutant ( $\triangle V d P L P-1-C$ and $\triangle V d P L P-4-C)$ strains after 21 days on basal agar modified medium (BMM) agar. Mean $( \pm \mathrm{SD})$ number of microsclerotia after: seven days on BMM agar (C); and 21 days on BMM agar (D). Three independent replicates were done; Different letters $(a-b)$ above the bars represent the significant differences among the groups and were analyzed with Duncan's multiple range test ( $p$-value $<0.05)$.

\section{4. $\triangle$ VdPLP Mutants Are Hypersensitive to Cell Wall-Perturbing Agents}

To determine whether the VdPLP gene was involved in maintaining cell wall integrity, we tested cell wall-perturbing agents CFW and CR for their effects on growth of the $\triangle V d P L P$ mutant strains. On PDA plates without CR or CFW, there was no significant difference between Vd-wt and the complementary $\triangle V d P L P$ strains in the colony diameter, but the colony diameter of $\triangle V d P L P$ strains showed nearly $50 \%$ reduction. On PDA plates containing $100 \mathrm{~g} / \mathrm{L} \mathrm{CR}$ or $50 \mathrm{~g} / \mathrm{L} \mathrm{CFW}$, the colony diameter of $\triangle V d P L P$ was significantly smaller than that of $\mathrm{Vd}-\mathrm{wt}$ and the complementary $\triangle V d P L P$ strains. Vd-wt and the complementary $\triangle V d P L P$ strains has no obvious growth defects on PDA plates with $100 \mathrm{~g} / \mathrm{L}$ CR or $50 \mathrm{~g} / \mathrm{L}$ CFW compared with growth on PDA without CR or CFW (Figure 4A,B). However, when $100 \mathrm{~g} / \mathrm{L} \mathrm{CR}$ or $50 \mathrm{~g} / \mathrm{L} C F W$ was added to the medium, the colony diameter of $\triangle V d P L P$ strains was significantly smaller than that of the colony on PDA without CR. These results indicated that $\triangle V d P L P$ strains were more sensitive to CR and CFW than the wild type and complementary strains, and $V d P L P$ was responsible for maintaining fungal cell wall integrity in $V$. dahliae. 

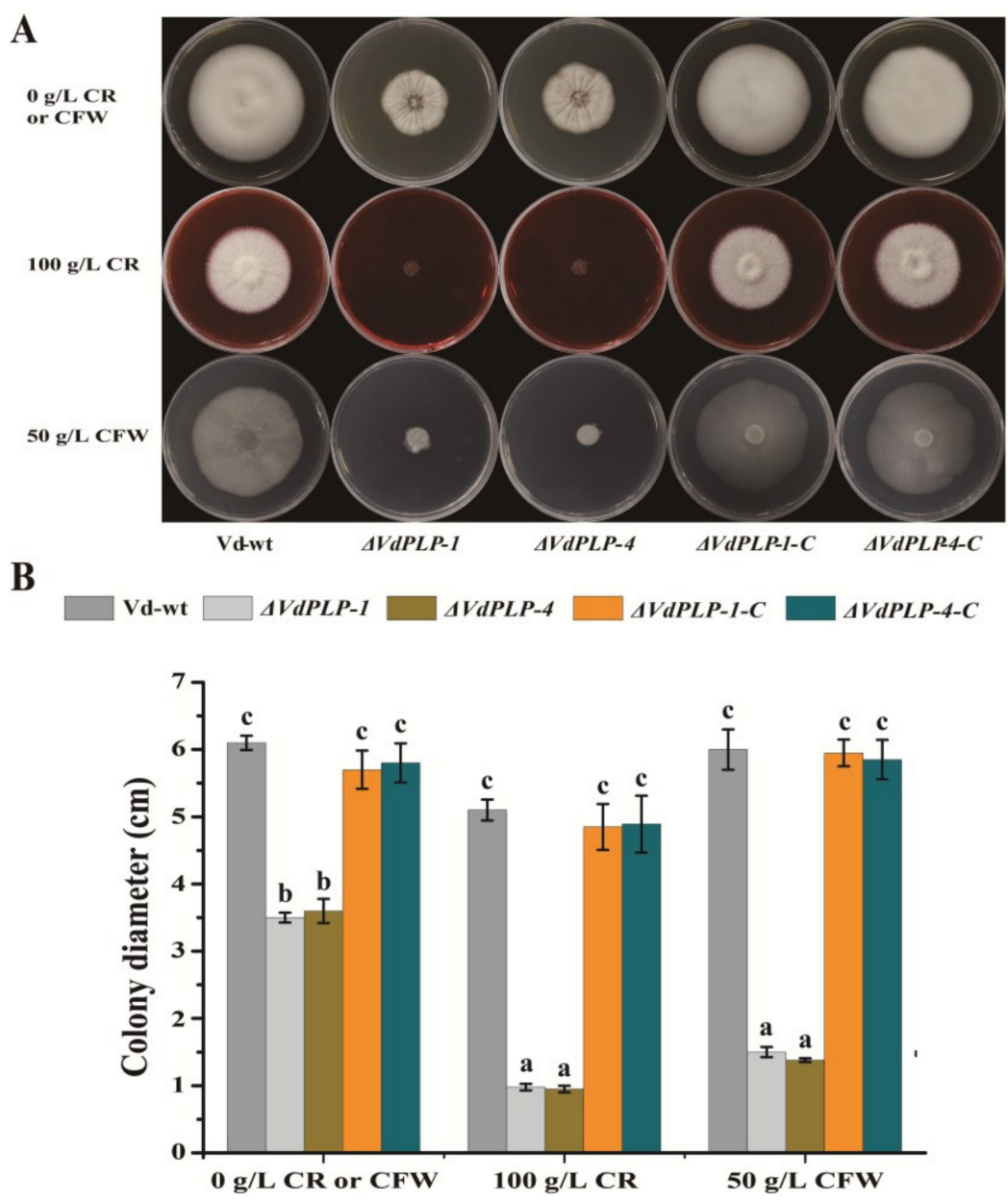

Figure 4. Effect of cell-wall-perturbing agents calcofluor white (CFW) and Congo red (CR) on growth of Vd-wt, $\triangle V d P L P(\triangle V d P L P-1$ and $\triangle V d P L P-4)$ strains, and complementary $\triangle V d P L P(\triangle V d P L P-1-C$ and $\triangle V d P L P-4-C)$ strains. (A) Colonies of Vd-wt, $\triangle V d P L P(\triangle V d P L P-1$ and $\triangle V d P L P-4)$ mutant strains, and complementary $\triangle V d P L P$ mutant $(\triangle V d P L P-1-C$ and $\triangle V d P L P-4-C)$ strains after 15 days on potato dextrose agar (PDA) plates containing $100 \mathrm{~g} / \mathrm{L} \mathrm{CR}$ or $50 \mathrm{~g} / \mathrm{L}$ CFW compared with controls on PDA at $25^{\circ} \mathrm{C}$. (B) Mean ( \pm SD) colony diameter after 15 days on PDA plates with $100 \mathrm{~g} / \mathrm{L} \mathrm{CR}$ or $50 \mathrm{~g} / \mathrm{L} \mathrm{CFW}$ compared with controls on PDA. Three independent replicates were done; Different letters $(\mathrm{a}-\mathrm{c})$ above the bars represent the significant differences among the groups and were analyzed with the Duncan's multiple range test ( $p$-value $<0.05)$.

\subsection{Genes for the Calcofluor White Pathway and for Chitin Synthesis in the $\triangle V$ VPLP Mutant Were Downregulated}

To further confirm that VdPLP contributes to the CWI pathway and chitin synthesis, we focused on the regulation of the CWI pathway by profiling transcript levels of the CWI pathway genes VdMKK1 and VdMK1 and chitin synthesis genes VdChi1,VdChi3, VdChi4, and VdChi7. In the $\triangle V d P L P$ mutant strains, transcription of $V d M K K 1, V d M K 1$, and the chitin synthesis genes all decreased compared with the wild type strain and complementary $\triangle V d P L P$ strains (Figure 5A-F). Downregulation of CWI and chitin synthesis genes indicated that VdPLP participates in the CWI pathway and chitin synthesis. 

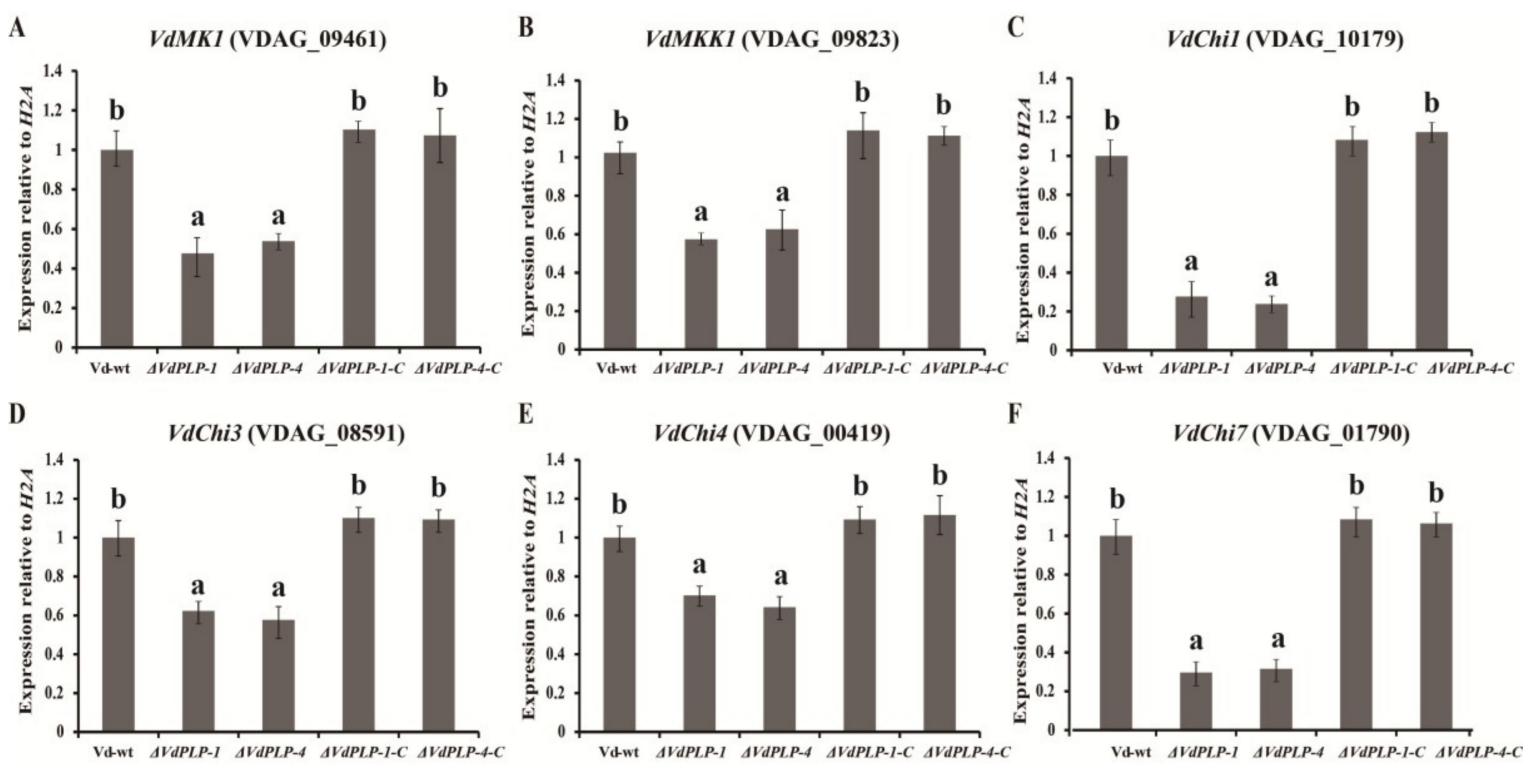

Figure 5. Expression of cell wall integrity (CWI) pathway genes (VdMKK1 (VDAG_09823) and VdMK1 (VDAG_09461)), and chitin synthesis genes (VdChi1 (VDAG_10179), VdChi3 (VDAG_08591), VdChi4 (VDAG_00419) and VdChi7 (VDAG_01790)) in the $\triangle V d P L P$ mutant strains ( $\triangle V d P L P-1$ and $\triangle V d P L P-4)$ was lower than in the $V$. dahliae wild type (Vd-wt) strain and complementary $\triangle V d P L P$ strains ( $\triangle V d P L P-1-C$ and $\triangle V d P L P-4-C)$. Total RNA was extracted from mycelia of seven-day-old Vd-wt, $\triangle V d P L P(\triangle V d P L P-1$ and $\triangle V d P L P-4)$, and complementary $\triangle V d P L P(\triangle V d P L P-1-C$ and $\triangle V d P L P-4-C)$ strains were grown in liquid complete medium (CM). Quantitative real-time reverse-transcription PCR was used to measure expression levels: $V d M K K 1$ (A); VdMK1 (B); VdChi1 (C); VdChi3 (D); VdChi4 (E); and $\operatorname{VdChi7}(\mathbf{F})$. The $\beta$-tubulin gene was used as an internal standard. Values are means $\pm \mathrm{SD}$ of three independent experiments performed in duplicates, significant differences are indicated by letters $(a, b)$, and data were analyzed with the Duncan's multiple range test $(p$-value $<0.05)$.

\subsection{Penetration and Fungal Colonization of $\triangle V d P L P$ Were Impaired}

To investigate possible reasons for the significant virulence defect of $\triangle V d P L P$ mutant strains, we analyzed penetration by the $\mathrm{Vd}-\mathrm{wt}, \triangle V d P L P$ and $\triangle V d P L P-C$ strains. After a conidial suspension of the respective strains was placed on cellophane membranes, Vd-wt and the $\triangle V d P L P-C$ strains penetrated and colonized the membranes, but no hyphae of the $\triangle V d P L P$ mutant strains grew (Figure 6A,B). Thus, the deletion of $V d P L P$ severely hindered the ability to penetrate the cellophane membrane.

GFP-labeled strains $\triangle V d P L P-4-G F P$ and $V d-G F P$ constitutively express GFP; strong green fluorescence thus allows observation of fungal penetration and colonization of plant root tissues using LSCM. Strain $V d$-GFP strain colonized $N$. benthamiana roots, and hyphae penetrated the epidermal and cortical cells. In contrast, few hyphae of the $\triangle V d P L P-4-G F P$ strain grew on the root, and the strain penetrated epidermal cells (Figure 6C). These phenomena indicate that VdPLP contributes to penetration and colonization by $V$. dahliae.

\subsection{VdPLP was Required for Fungal Pathogenicity}

To verify the role of $V d P L P$ in fungal pathogenicity, we inoculated roots of $N$. benthamiana seedlings with a conidial suspension of $\mathrm{Vd}-\mathrm{wt}, \triangle V d P L P$, or $\triangle V d P L P-C$ strains. As expected, at 8, 10, and $12 \mathrm{dpi}$, plants inoculated with either $\mathrm{Vd}-\mathrm{wt}$, or the complementary strains developed significant wilting, whereas only a few chlorotic leaves appeared on plants inoculated with $\triangle V d P L P$ strains. At 12 dpi, plants inoculated with $\mathrm{Vd}-\mathrm{wt}$ or $\triangle V d P L P-C$ strains were stunted, chlorotic, wilting or dead. In contrast, the seedlings infected with $\triangle V d P L P$ mutants exhibited mild symptoms, with interveinal chlorosis on 
the bottom 1 or 2 leaves, but no necrosis (Figure 7A,B). Furthermore, when biomass was quantified, less fungal DNA was detected from infected plants inoculated with the $\triangle V d P L P$ strains than with $\mathrm{Vd}$-wt or the $\triangle V d P L P-C$ strains (Figure $7 \mathrm{C}$ ). The decrease in symptoms and biomass suggest that $V d P L P$ disruption reduced the virulence of $V$. dahliae.

A

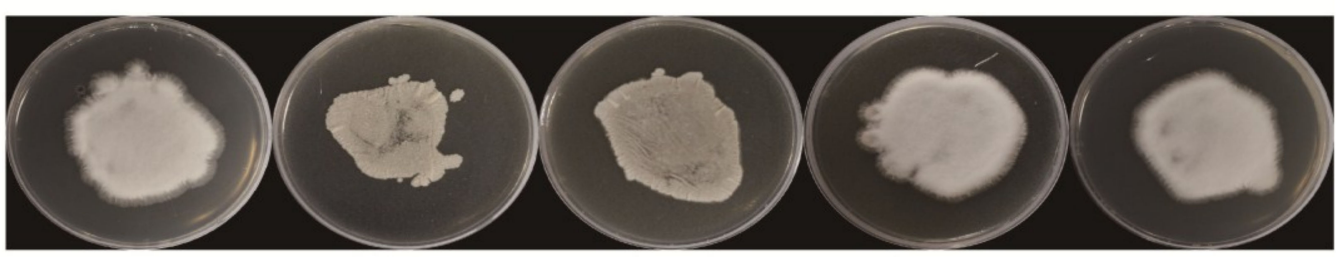

B

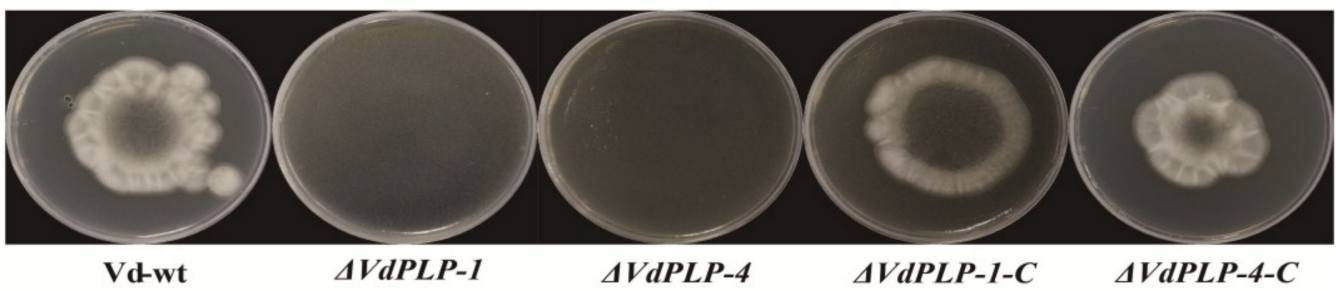

C

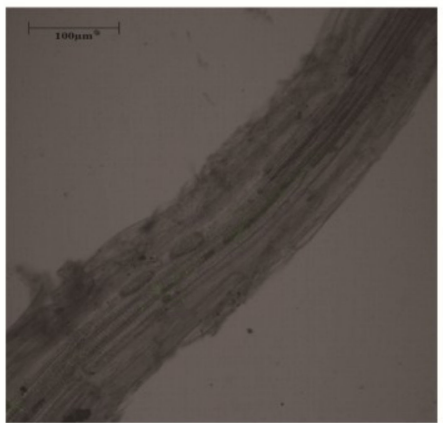

Mock

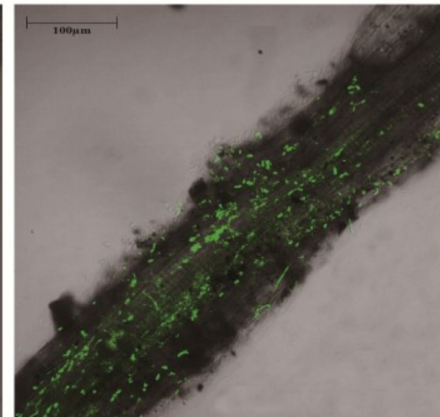

$V d-G F P$

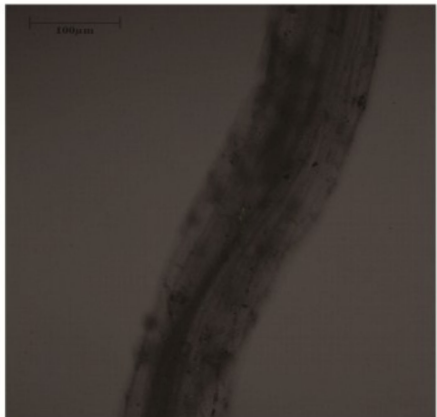

$\triangle V d P L P-4-G F P$

Figure 6. Fungal colonization and penetration assay: (A) Vd-wt, $\triangle V d P L P$ and $\triangle V d P L P-C$ strains grown on cellophane for three days after strains had penetrated a cellophane membrane on the agar plate and membranes were removed; (B) plates after incubation at $25^{\circ} \mathrm{C}$ for seven days after cellophane were removed; and (C) fungal colonization of infected roots by the $\triangle V d P L P-4-G F P$ mutant strains, Vd-GFP strain, and sterile water (Mock), three days after inoculation.

\section{Discussion}

Phospholipases also regulate vegetative growth signals in filamentous fungi $[9,13,21,22,50]$. The cAMP-specific PDEs can be regulated by some phospholipases, which adjust intracellular cAMP level. cAMP signaling participates in numerous intracellular activities [23,24]. For example, the constitutive activation of cAMP phosphodiesterase, which can activate the cAMP pathway, influences the biosynthesis and structure of the cell wall and membrane [51,52]. Fungal phospholipases affect blastospore development [18] and participate in hyphal extension in the filamentous fungi N. crassa [19], C. cinerea [20], and M. oryzae [25,28]. Due to inhibition of phosphodiesterase activity in $V$. dahliae, conidial production and virulence was reduced in G protein $\beta$ subunit gene (VGB) mutants [53]. Similar phenotypic changes were observed in VdPLP deletion mutants. Hyphal growth of $\triangle V A P L P$ strains under different carbon sources conditions, and conidia production was drastically reduced compared with the wild type strain and complementation mutants, which suggested that impaired vegetative growth and conidial production caused by VdPLP deletion may be the reason for the virulence decline.

Microsclerotia, melanized survival structures that can survive in the soil for more than ten years in the absence of host plants, play a critical role in the disease cycle of $V$. dahliae, but the molecular 
mechanism of their biogenesis is still not clear [54-57]. VdPKAC1 mutants showed a decrease in fungal virulence and an increase in microsclerotial formation [58]. In contrast, microsclerotia production decreased by $V$. dahliae class II hydrophobin gene (VDH1) mutants [59], Vayg1 deletion mutants [60], transmembrane mucin Msb (VdMsb) mutants [61] and MAPK mutants [62]. In the present laboratory study, $\triangle V d P L P$ mutants produced microsclerotia earlier and in greater numbers than did $\mathrm{Vd}-\mathrm{wt}$ and the $\triangle V d P L P-C$ strains. Based on the above research, opposite results for mutants in different genes suggest that the molecular mechanisms of microsclerotia formation are complex. Regulatory genes such as $V d P K A C 1, V D H 1, V a y g 1, V d M s b$, and dihydroxynaphthalene (DHN) melanin biosynthesis pathway [57] may regulate the microsclerotia biosynthesis. The loss of VdPLP likely activates microsclerotia production via participating in a signaling pathway, but the specific mechanisms of the transition from vegetative growth to resting structure development require further research.

A
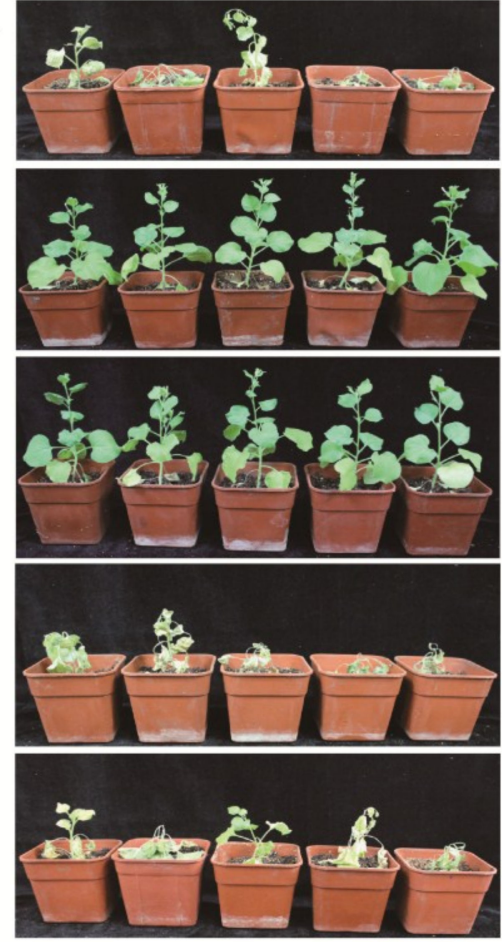

B

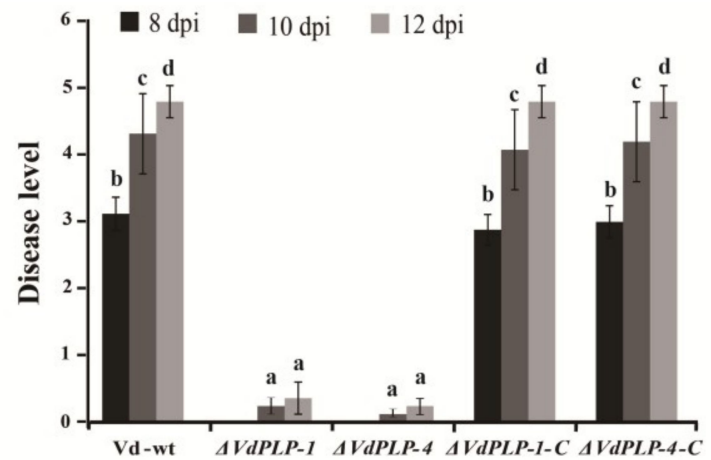

IVdPLP-4

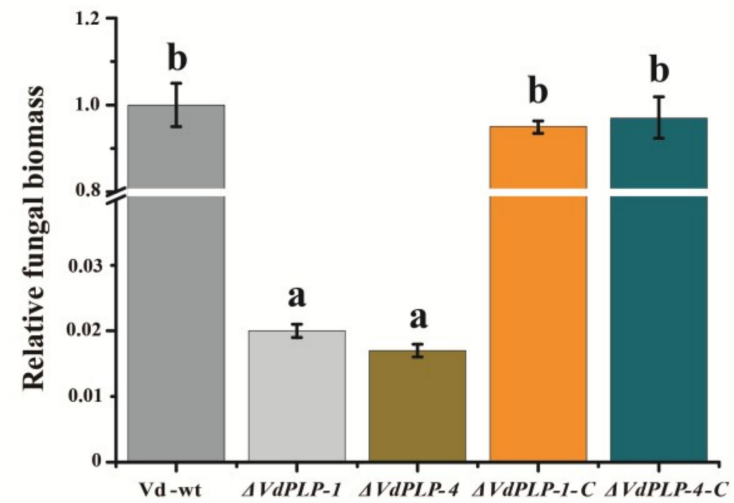

Figure 7. $\triangle V d P L P$ mutant strains were not virulent on Nicotiana benthamiana in pathogenicity assays. (A) Representative plants 12 days post inoculation (dpi) with Vd-wt, $\triangle V d P L P$ strains ( $\triangle V d P L P-1$ and $\triangle V d P L P-4)$, or complementary $\triangle V d P L P$ strains ( $\triangle V d P L P-1-C$ and $\triangle V d P L P-4-C)$; (B) Disease level on $N$. benthamiana after a 2-min root-dip in conidia of the Vd-wt, $\triangle V d P L P$ strains $(\triangle V d P L P-2$ and $\triangle V d P L P-4)$, and complementary $\triangle V d P L P$ mutant $(\triangle V d P L P-1-C$ and $\triangle V d P L P-4-C)$ strains at 8 , 10 , and $12 \mathrm{dpi}$. See methods for severity scale; (C) Relative quantification of fungal biomass in $N$. benthamiana stems inoculated with conidial suspension of Vd-wt, $\triangle V d P L P$ strains $(\triangle V d P L P-1$ and $\triangle V d P L P-4)$, and complementation $\triangle V d P L P$ strains ( $\triangle V d P L P-1-C$ and $\triangle V d P L P-4-C)$ at 12 dpi. Values are means \pm SD from three independent replicates. Significant differences are indicated by letters $(a-d)$, Duncan's multiple range test $(p$-value $<0.05)$ was used to analyze significant difference between each group.

The fungal cell wall plays a critical role in maintaining cell shape, protecting against physical injury, and mediating exchanges between pathogenic fungi and their hosts [62-64]. It also provides adhesive properties and protection against host defenses, which is imperative for pathogenicity in fungi $[63,65,66]$. PdeH are related to cell wall integrity, stress response and virulence in $M$. oryzae and C. albicans [25,28,50-52]. MoPdeH targets MoMck1 of M. oryzae, one of the components of the MAPK 
cascade, and regulates cell wall integrity and virulence [28]. Integrity of the cell wall is critical for penetration of the host and thus for fungal virulence [67]. In this study, deletion of VdPLP generated $\triangle V d P L P$ mutants that were sensitive to cell wall-perturbing agents, which suggests $V d P L P$ participates in stabilizing the cell wall under stress. Disruption of cell wall integrity in the VdPLP mutants was thus associated with the significantly reduced virulence of the $\triangle V A P L P$ mutants.

A small G protein, Rho1, is considered to be the master regulator of CWI signaling. Rho1 integrates signals from the cell surface and regulates many outputs involved in cell wall biogenesis. GTP-bound Rho1 associates with and activate the PKC1 [47]. Polyunsaturated fatty acids like arachidonic acid (AA) released by PLPs may regulate cellular signaling and influence the activity of protein kinases [35]. MAPK pathway can be regulated by protein kinases [30,31]. Thus, PLPs could influence the MAPK pathway and CWI pathway as well. In the citrus postharvest pathogen Penicillium digitatum, disruption of chitin synthase (PdChsVII) impaired CWI integrity, causing reduced virulence [68]. Class I chitin synthases reinforce cell wall integrity under a specific cell wall stress in C. albicans [69]. A myosin motor domain-chitin synthases (MMD-Chs) deletion impaired fungal resistance to host defense mechanisms and colonization by invasive hyphae, possibly due to a decrease in the structural integrity and permeability of the cell wall [70]. In our research, the expression of the MAPK pathway (VdMK1 and $V d M K K 1)$ was diminished in the $\triangle V d P L P$ mutants. The CWI pathway and chitin synthesis genes were downregulated in the $\triangle V d P L P$ strains, suggesting that $V d P L P$ has a critical role in regulating the $C W I$ pathway and chitin synthesis in $V$. dahliae. Meanwhile, $\triangle V d P L P$ mutants cannot penetrate the cellophane membrane. GFP-labeled $\triangle V d P L P$ mutants showed impairment in colonization. The results indicate that VdPLP could regulate the MAPK pathway for regulating CWI pathway and chitin synthase and affect the cell wall integrity and virulence of $V$. dahliae.

Soil-borne $V$. dahliae must penetrate and colonize the root to cause disease. The colonization of Arabidopsis thaliana [71], cotton [6] and tomato [72] by V. dahliae GFP-labeled strains has been detailed. In our research, the same strategy was used for penetration ability comparison. When the penetration ability of GFP-tagged $\triangle V d P L P$ strains was compared with that of $V d$-GFP strains, penetration of epidermal cells of the roots by hyphae of $\triangle V d P L P$-GFP strains was severely lowered as was subsequent colonization. In addition, $\triangle V d P L P$ strains were impaired in penetration of cellophane, indicating impairment of an early phase of infection. $V d P L P$ may regulate vegetative growth of $V$. dahliae in plant tissue and affect cell wall stability, and then impair pathogenicity further.

Deletion of $V d P L P$ resulted in severe impairment of vegetative growth on various carbon sources and reduced conidia production. The $\triangle V d P L P$ mutants were also severely impaired in their ability to penetrate and colonize roots of $N$. benthamiana, as shown microscopically and by a decrease in biomass compared with the wild type. The qRT-PCR results suggest that VdPLP participates in the CWI pathway and chitin synthesis. These results revealed the defect of $\triangle V d P L P$ mutants to penetrate plant tissue, contributing to the impaired virulence. VdPLP may contribute to the full virulence of $V$. dahliae by mediating hyphal growth, the cell wall integrity and penetration process, which provides new insights into the molecular pathogenic mechanisms of $V$. dahliae.

Acknowledgments: This work was supported by a grant from the National Natural Science Foundation of China (31772244), the National Nonprofit Industry Research (201503109) and the Agricultural Science and Technology Innovation Program of Chinese Academy of Agricultural Science (CAAS). We thank Guiliang Jian (Institute of Plant Protection, CAAS) for kindly providing the $V$. dahliae strain 991.

Author Contributions: Hongmei Cheng and Xiliang Qi conceived and designed the experiments; Xiliang Qi and Xiaokang Li performed the experiments; Xiliang Qi, Xiaokang Li and Huiming Guo analyzed the data; Huiming Guo and Hongmei Cheng guided the writing; Ning Guo contributed analysis tools; and Xiliang Qi and Xiaokang Li wrote the paper.

Conflicts of Interest: The authors have declared that no conflict of interest exists. 


\section{References}

1. Fradin, E.F.; Thomma, B.P. Physiology and molecular aspects of Verticillium wilt diseases caused by V. dahliae and V. albo-atrum. Mol. Plant Pathol. 2006, 7, 71-86. [CrossRef] [PubMed]

2. Klosterman, S.J.; Atallah, Z.K.; Vallad, G.E.; Subbarao, K.V. Diversity, pathogenicity, and management of Verticillium species. Annu. Rev. Phytopathol. 2009, 47, 39-62. [CrossRef] [PubMed]

3. Cai, Y.F.; He, X.H.; Mo, J.C.; Sun, Q.; Yang, J.P.; Liu, J.G. Molecular research and genetic engineering of resistance to Verticillium wilt in cotton: A review. Afr. J. Biotechnol. 2009, 8, 7363-7372.

4. Klosterman, S.J.; Subbarao, K.V.; Kang, S.; Veronese, P.; Gold, S.E.; Thomma, B.; Chen, Z.; Henrissat, B.P.; Chen, Z.H.; Henrissat, B.; et al. Comparative genomics yields insights into niche adaptation of plant vascular wilt pathogens. PLoS Pathog. 2011, 7, e1002137. [CrossRef] [PubMed]

5. Klimes, A.; Dobinson, K.F. A hydrophobin gene, VDH1, is involved in microsclerotial development and spore viability in the plant pathogen Verticillium dahliae. Fungal Genet. Biol. 2006, 43, 283-294. [CrossRef] [PubMed]

6. Zhao, Y.L.; Zhou, T.T.; Guo, H.S. Hyphopodium-specific VdNoxB/VdPls1-dependent ROS-Ca ${ }^{2+}$ signaling is required for plant infection by Verticillium dahliae. PLoS Pathog. 2016, 12, e1005793. [CrossRef] [PubMed]

7. Luo, X.M.; Xie, C.J.; Dong, J.Y.; Yang, X.Y.; Sui, A.P. Interactions between Verticillium dahliae and its host: Vegetative growth, pathogenicity, plant immunity. Appl. Microbiol. Biotechnol. 2014, 98, 6921-6932. [CrossRef] [PubMed]

8. Qi, X.L.; Su, X.F.; Guo, H.M.; Qi, J.C.; Cheng, H.M. VdThit, a thiamine transport protein, is required for pathogenicity of the vascular pathogen Verticillium dahliae. Mol. Plant-Microbe Interact. 2016, 29, 545-559. [CrossRef] [PubMed]

9. Ghannoum, M.A. Potential role of phospholipases in virulence and fungal pathogenesis. Clin. Microbiol. Rev. 2000, 13, 122-143. [CrossRef] [PubMed]

10. Ramrakhiani, L.; Chand, S. Recent progress on phospholipases: Different sources, assay methods, industrial potential and pathogenicity. Appl. Biochem. Biotechnol. 2011, 164, 991-1022. [CrossRef] [PubMed]

11. David, A.S.; Edward, A.D. The expanding superfamily of phospholipase A2 enzymes: Classification and characterization. Biochim. Biophys. Acta 2000, 1488, 1-19.

12. Theiss, S.; Ishdorj, G.; Brenot, A.; Kretschmar, M.; Lan, C.Y.; Nichterlein, T.; Hacker, J.; Nigam, S.; Agabian, N.; Köhler, G.A. Inactivation of the phospholipase B gene PLB5 in wild-type Candida albicans reduces cell-associated phospholipase $\mathrm{A}_{2}$ activity and attenuates virulence. Int. J. Med. Microbiol. 2006, 296, 405-420. [CrossRef] [PubMed]

13. Köhler, G.A.; Brenot, A.; Haas-Stapleton, E.; Agabian, N.; Deva, R.; Nigam, S. Phospholipase A2 and Phospholipase B Activities in Fungi. Biochim. Biophys. Acta 2006, 1761, 1391-1399. [CrossRef] [PubMed]

14. Zhu, Q.; Sun, L.; Lian, J.; Gao, X.; Zhao, L.; Ding, M.; Li, J.; Liang, Y. The phospholipase C (FgPLC1) is involved in regulation of development, pathogenicity, and stress responses in Fusarium graminearum. Fungal Genet. Biol. 2016, 97, 1-9. [CrossRef] [PubMed]

15. Rhee, S.G. Regulation of phosphoinositide-specific Phospholipase C. Annu. Rev. Biochem. 2001, 70, $281-312$. [CrossRef] [PubMed]

16. Exton, J.H. Phospholipase D-structure, regulation and function. Rev. Physiol. Biochem. Pharmacol. 2002, 144, 1-94. [PubMed]

17. Barrett-Bee, K.; Hayes, Y.; Wilson, R.G.; Ryley, J.F. A comparison of phospholipase activity, cellular adherence and pathogenicity of yeasts. J. Gen. Microbiol. 1985, 131, 1217-1221. [CrossRef] [PubMed]

18. Pugh, D.; Cawson, R.A. The cytochemical localization of phospholipase A and lysophospholipase in Candida albicans. Sabouraudia 1975, 13, 110-115. [CrossRef] [PubMed]

19. Lew, R.R.; Giblon, R.E.; Lorenti, M.S.H. The phenotype of a phospholipase C (plc-1) mutant in a filamentous fungus Neurospora crassa. Fungal Genet. Biol. 2015, 82, 158-167. [CrossRef] [PubMed]

20. Oh, Y.T.; Ahn, C.S.; Lee, K.J.; Kim, J.G.; Ro, H.S.; Kim, J.W.; Lee, C.W. The activity of phosphoinositide-specific phospholipase $\mathrm{C}$ is required for vegetative growth and cell wall regeneration in Coprinopsis cinerea. J. Microbiol. 2012, 50, 689-692. [CrossRef] [PubMed]

21. Soragni, E.; Bolchi, A.; Balestrini, R.; Gambaretto, C.; Percudani, R.; Bonfante, P.; Ottonello, S. A nutrient-regulated, dual localization phospholipase A2 in the symbiotic fungus Tuber borchii. EMBO J. 2001, 20, 5079-5090. [CrossRef] [PubMed] 
22. Nakahama, T.; Nakanishi, Y.; Viscomi, A.R.; Takaya, K.; Kitamoto, K.; Ottonello, S.; Arioka, M. Distinct enzymatic and cellular characteristics of two secretory phospholipases A2 in the filamentous fungus Aspergillus oryzae. Fungal Genet. Biol. 2010, 47, 318-331. [CrossRef] [PubMed]

23. Grange, M.; Sette, C.; Cuomo, M.; Conti, M.; Lagarde, M.; Prigent, A.F.; Némoz, G. The cAMP-specific phosphodiesterase PDE4D3 is regulated by phosphatidic acid binding. Consequences for cAMP signaling pathway and characterization of a phosphatidic acid binding site. J. Biol. Chem. 2000, 275, 33379-33387. [CrossRef] [PubMed]

24. Liu, Y.; Su, Y.; Wang, X. Phosphatidic Acid-Mediated Signaling. In Lipid-Mediated Protein Signaling, 1st ed.; Capelluto, D.G.S., Ed.; Springer: Dordrecht, The Netherlands, 2013; ISBN 978-94-007-6331-9.

25. Zhang, H.; Liu, K.; Zhang, X.; Tang, W.; Wang, J.; Guo, M.; Zhao, Q.; Zheng, X. Two phosphodiesterase genes, $P D E L$ and $P D E H$, regulate development and pathogenicity by modulating intracellular cyclic AMP levels in Magnaporthe oryzae. PLoS ONE 2011, 6, e17241. [CrossRef] [PubMed]

26. Ramanujam, R.; Naqvi, N.I. PdeH, a high-affinity cAMP Phosphodiesterase, is a key regulator of asexual and pathogenic differentiation in Magnaporthe oryzae. PLoS Pathog. 2010, 6, e1000897. [CrossRef] [PubMed]

27. Alonso-Rodríguez, E.; Fernández-Piñar, P.; Sacristán-Reviriego, A.; Molina, M.; Martín, H. An analog-sensitive version of the protein kinase Slt2 allows identification of novel targets of the yeast cell wall integrity pathway. J. Biol. Chem. 2016, 291, 5461-5472. [CrossRef] [PubMed]

28. Yin, Z.; Tang, W.; Wang, J.; Liu, X.; Yang, L.; Gao, C.; Zhang, J.L.; Zhang, H.F.; Zheng, X.B.; Wang, P.; et al. Phosphodiesterase MoPdeH targets MoMck1 of the conserved mitogen-activated protein (MAP) kinase signaling pathway to regulate cell wall integrity in rice blast fungus Magnaporthe oryzae. Mol. Plant Pathol. 2016, 17, 654-668. [CrossRef] [PubMed]

29. Sacristán-Reviriego, A.; Martín, H.; Molina, M. Identification of putative negative regulators of yeast signaling through a screening for protein phosphatases acting on cell wall integrity and mating MAPK pathways. Fungal Genet. Biol. 2015, 77, 1-11. [CrossRef] [PubMed]

30. Arias, P.; Díez-Muñiz, S.; García, R.; Nombela, C.; Rodríguez-Peña, J.M.; Arroyo, J. Genome-wide survey of yeast mutations leading to activation of the yeast cell integrity MAPK pathway Novel insights into diverse MAPK outcomes. BMC Genom. 2011, 12, 390. [CrossRef] [PubMed]

31. Chen, R.E.; Thorner, J. Function and regulation in MAPK signaling pathways lessons learned from the yeast Saccharomyces cerevisiae. Biochim. Biophys. Acta 2007, 1773, 1311-1340. [CrossRef] [PubMed]

32. García, R.; Bermejo, C.; Grau, C.; Pérez, R.; Rodríguez-Peña, J.M.; Francois, J.; Nombela, C.; Arroyo, J. The global transcriptional response to transient cell wall damage in Saccharomyces cerevisiae and its regulation by the cell integrity signaling pathway. J. Biol. Chem. 2004, 279, 15183-15195. [CrossRef] [PubMed]

33. Levin, D.E. Cell wall integrity signaling in Saccharomyces cerevisiae. Microbiol. Mol. Biol. Rev. 2005, 69, $262-291$. [CrossRef] [PubMed]

34. Lesage, G.; Bussey, H. Cell wall assembly in Saccharomyces cerevisiae. Microbiol. Mol. Biol. Rev. 2006, 70, 317-343. [CrossRef] [PubMed]

35. Wilson, S.K.; Knoll, L.J. Patatin-like phospholipases in microbial infections with emerging roles in fatty acid metabolism and immune regulation by Apicomplexa. Mol. Micobiol. 2017, 107, 34-36. [CrossRef] [PubMed]

36. Lévêque, M.F.; Berry, L.; Yamaryo-Botté, Y.; Nguyen, H.M.; Galera, M.; Botté, C.Y.; Besteiro, S. TgPL2, a patatin-like phospholipase domain-containing protein, is involved in the maintenance of apicoplast lipids homeostasis in Toxoplasma. Mol. Microbiol. 2017, 105, 158-174. [CrossRef] [PubMed]

37. Anderson, D.M.; Sato, H.; Dirck, A.T.; Feix, J.B.; Frank, D.W. Ubiquitin activates Patatin-like Phospholipases from multiple bacterial species. J. Bacteriol. 2015, 197, 529-541. [CrossRef] [PubMed]

38. Strickland, J.A.; Walsh, T.A. Inhibition of Diabrotica larval growth by Patatin, the lipid acyl hydrolase from potato tubers. Plant Physiol. 1995, 109, 667-674. [CrossRef] [PubMed]

39. Qi, X.L.; Su, X.F.; Guo, H.M.; Qi, J.C.; Cheng, H.M. A ku70 null mutant improves gene targeting frequency in the fungal pathogen Verticillium dahliae. World J. Microbiol. Biotechnol. 2015, 31, 1889-1897. [CrossRef] [PubMed]

40. Khang, C.H.; Park, S.Y.; Lee, H.Y.; Kang, S. A dual selection based, targeted gene replacement tool for Magnaporthe grisea and Fusarium oxysporum. Fungal Genet. Biol. 2005, 35, 624-633. [CrossRef] [PubMed]

41. Rehman, L.; Su, X.F.; Guo, H.M.; Qi, X.L.; Cheng, H.M. Protoplast transformation as a potential platform for exploring gene function in Verticillium dahliae. BMC Biotechnol. 2016, 16, 57-65. [CrossRef] [PubMed] 
42. Bai, Y.W.; Hu, D.F.; Hu, X.P.; Zhao, J.X.; Zhu, H.Q.; Yang, J.R. Formation conditions for microsclerotia of Verticillium dahliae. Mycosystema 2011, 30, 695-701.

43. Ram, A.F.; Klis, F.M. Identification of fungal cell wall mutants using susceptibility assays based on Calcofluor white and Congo red. Nat. Protoc. 2006, 1, 2253-2256. [CrossRef] [PubMed]

44. Tian, H.; Zhou, L.; Guo, W.; Wang, X. Small GTPase Rac1 and its interaction partner Cla4 regulate polarized growth and pathogenicity in Verticillium dahliae. Fungal Genet. Biol. 2015, 74, 21-31. [CrossRef] [PubMed]

45. Zhao, Y.L.; Zhang, T.; Guo, H.S. Penetration assays, fungal recovery and pathogenicity assays for Verticillium dahliae. Bio-Protocol 2017, 7, 1-8. [CrossRef]

46. Zhang, T.; Zhang, B.S.; Hua, C.L.; Meng, P.; Wang, S.; Chen, Z.R.; Du, Y.J.; Gao, F.; Huang, J.F. VdPKS1 is required for melanin formation and virulence in a cotton wilt pathogen Verticillium dahliae. Sci. China Life Sci. 2017, 60, 695-701. [CrossRef] [PubMed]

47. Levin, D.E. Regulation of cell wall biogenesis in Saccharomyces cerevisiae: The cell wall integrity signaling pathway. Genetics 2011, 189, 1145-1175. [CrossRef] [PubMed]

48. García, R.; Rodríguez-Peña, J.M.; Bermejo, C.; Nombela, C.; Arroyo, J. The high osmotic response and cell wall integrity pathways cooperate to regulate transcriptional responses to zymolyase-induced cell wall stress in Saccharomyces cerevisiae. J. Biol. Chem. 2009, 284, 10901-10911. [CrossRef] [PubMed]

49. Valiante, V.; Jain, R.; Heinekamp, T.; Brakhage, A.A. The MpkA MAP kinase module regulates cell wall integrity signaling and pyomelanin formation in Aspergillus fumigatus. Fungal Genet. Biol. 2009, 46, 909-918. [CrossRef]

50. Aloulou, A.; Ali, Y.B.; Bezzine, S.; Gargouri, Y. Gelb MH. Phospholipases: An overview. Methods Mol. Biol. 2012, 861, 63-85. [PubMed]

51. Park, J.I.; Grant, C.M.; Dawes, I.W. The high-affinity cAMP phosphodies-terase of Saccharomyces cerevisiae is the major determinant of cAMP levels in stationary phase: Involvement of different branches of the Ras-cyclic AMP pathway in stress responses. Biochem. Biophys. Res. Commun. 2005, 327, 311-319. [CrossRef] [PubMed]

52. Wilson, D.; Tutulan-Cunita, A.; Jung, W.; Hauser, N.C.; Hernandez, R.; Williamson, T.; Piekarska, K.; Rupp, S.; Young, T.; Stateva, L. Deletion of the high-affinity cAMP phosphodiesterase encoded by PDE2 affects stress responses and virulence in Candida albicans. Mol. Microbiol. 2007, 65, 841-856. [CrossRef] [PubMed]

53. Tzima, A.K.; Paplomatas, E.J.; Tsitsigiannis, D.I.; Kang, S. The G protein $\beta$ subunit controls virulence and multiple growth- and development-related traits in Verticillium dahliae. Fungal Genet. Biol. 2012, 49, 271-283. [CrossRef] [PubMed]

54. Coley-Smith, J.R.; Cooke, R.C. Survival and germination of fungal sclerotia. Annu. Rev. Phytopathol. 1971, 9, 65-92. [CrossRef]

55. Hawke, M.A.; Lazarovits, G. Production and manipulation of individual microsclerotia of Verticillium dahliae for use in studies of survival. Phytopathology 1994, 23, 582-584.

56. Klimes, A.; Amyotte, S.G.; Grant, S.; Kang, S.; Dobinson, K.F. Microsclerotia development in Verticillium dahliae: Regulation and differential expression of the hydrophobin gene VDH1. Fungal Genet. Biol. 2008, 45, 1525-1532. [CrossRef] [PubMed]

57. Dechassa, D.; Amy, A.; Chen, D. RNA-seq analyses of gene expression in the microsclerotia of Verticillium dahliae. BMC Genom. 2013, 14, 607. [CrossRef]

58. Tzima, A.; Paplomatas, E.J.; Rauyaree, P.; Kang, S.C. Roles of the catalytic subunit of cAMP-dependent protein kinase A in virulence and development of the soilborne plant pathogen Verticillium dahliae. Fungal Genet. Biol. 2010, 47, 406-415. [CrossRef] [PubMed]

59. Fan, R.; Klosterman, S.J.; Wang, C.; Subbarao, K.V.; Xu, X.; Shang, W.; Hu, X. Vayg1 is required for microsclerotium formation and melanin production in Verticillium dahliae. Fungal Genet. Biol. 2017, 98, 1-11. [CrossRef] [PubMed]

60. Tian, L.; Xu, J.; Zhou, L.; Guo, W. VdMsb regulates virulence and microsclerotia production in the fungal plant pathogen Verticillium dahliae. Gene 2014, 550, 238-244. [CrossRef] [PubMed]

61. Rauyaree, P.; Ospina, G.S.; Bhat, R.G.; Subbarao, K.V.; Grant, S.J.; Dobinson, K.F. Mutations in VMK1, a mitogen-activated protein kinase gene, affect microsclerotia formation and pathogenicity in Verticillium dahliae. Curr. Genet. 2005, 48, 109-116. [CrossRef] [PubMed]

62. Gil-Bona, A.; Parra-Giraldo, C.M.; Hernáez, M.L.; Reales-Calderon, J.A.; Solis, N.V.; Filler, S.G.; Monteoliva, L.; Gil, C. Candida albicans cell shaving uncovers new proteins involved in cell wall integrity, 
yeast to hypha transition, stress response and host-pathogen interaction. J. Proteom. 2015, 127, 340-351. [CrossRef] [PubMed]

63. Gil-Bona, A.; Reales-Calderon, J.A.; Parra-Giraldo, C.M.; Martinez-Lopez, R.; Monteoliva, L.; Gil, C. The cell wall protein Ecm33 of Candida albicans is involved in chronological life span, morphogenesis, cell wall regeneration, stress tolerance, and host-cell interaction. Front. Microbiol. 2016, 7, 64. [CrossRef] [PubMed]

64. Klis, F.M.; Sosinska, G.J.; De Groot, P.W.; Brul, S. Covalently linked cell wall proteins of Candida albicans and their role in fitness and virulence. FEMS Yeast Res. 2009, 9, 1013-1028. [CrossRef] [PubMed]

65. Bowman, S.M.; Free, S.J. The structure and synthesis of the fungal cell wall. Bioessays 2006, 28, 799-808. [CrossRef] [PubMed]

66. Chaffin, W.L. Candida albicans cell wall proteins. Microbiol. Mol. Biol. Rev. 2008, 72, 495-544. [CrossRef] [PubMed]

67. Guo, M.; Gao, F.; Zhu, X.; Nie, X.; Pan, Y.; Gao, Z. MoGrr1, a novel F-box protein, is involved in conidiogenesis and cell wall integrity and is critical for the full virulence of Magnaporthe oryzae. Appl. Microbiol. Biotechnol. 2015, 99, 8075-8088. [CrossRef] [PubMed]

68. Gandía, M.; Harries, E.; Marcos, J.F. The myosin motor domain-containing chitin synthase PdChsVII is required for development, cell wall integrity and virulence in the citrus postharvest pathogen Penicillium digitatum. Fungal Genet. Biol. 2014, 67, 58-70. [CrossRef] [PubMed]

69. Preechasuth, K.; Anderson, J.C.; Peck, S.C.; Brown, A.J.; Gow, N.A.; Lenardon, M.D. Cell wall protection by the Candida albicans class I chitin synthases. Fungal Genet. Biol. 2015, 82, 264-276. [CrossRef] [PubMed]

70. Fernandes, C.; Gow, N.A.; Gonçalves, T. The importance of subclasses of chitin synthase enzymes with myosin-like domains for the fitness of fungi. Fungal Biol. Rev. 2016, 30, 1-14. [CrossRef]

71. Zhao, P.; Zhao, Y.L.; Jin, Y.; Zhang, T.; Guo, H.S. Colonization process of Arabidopsis thaliana roots by a green fluorescent protein-tagged isolate of Verticillium dahliae. Protein Cell 2014, 5, 94-98. [CrossRef] [PubMed]

72. Sarmiento-Villamil, J.L.; Prieto, P.; Klosterman, S.J.; García-Pedrajas, M.D. Characterization of two homeodomain transcription factors with critical but distinct roles in virulence in the vascular pathogen Verticillium dahliae. Mol. Plant Pathol. 2017. [CrossRef] [PubMed] 